\title{
Trends of storms in N W Europe derived from an updated pressure data set
}

\author{
Hans Alexandersson ${ }^{1, *}$, Heikki Tuomenvirta ${ }^{2}$, Torben Schmith ${ }^{3}$, Knut Iden ${ }^{4}$ \\ ${ }^{1}$ Swedish Meteorological and Hydrological Institute, 60176 N orrköping, Sweden \\ ${ }^{2}$ Finnish Meteorological Institute, PO Box 503, 00101 Helsinki, Finland \\ ${ }^{3}$ Danish M eteorological Institute, Lyngbyvej 100, 2100 C openhagen, Denmark \\ ${ }^{4}$ The N orwegian M eteorological Institute, Postboks 43 Blindern, 0313 Oslo, N orway
}

\begin{abstract}
Within the WASA project (von Storch et al. 1998; Bull Am Meterol Soc 79(5):741-760) an extensive data set containing station pressure values was used to calculate geostrophic winds (Alexandersson et al. 1998; Global Atmos Ocean Syst 6:97-120). Geostrophic winds were analysed in terms of percentiles to give a measure of long-term variations in synoptic-scale storminess. In this paper an update to 1998 is presented. In the Scandinavia, Finland and Baltic Sea area the most recent years, especially the cold and calm year 1996, seem to have brought an end to the stormy period centred on 1990. In the more westerly British Isles, North Sea and Norwegian Sea area, storminess is still at high levels compared with the less intense period between 1930 and 1980. The long-term increasing trend in NW Europe storminess that started in the 1960s seems to have been broken.
\end{abstract}

KEY WORDS: Geostrophic winds · Storm statistics · Storm trends · Northwestern Europe

Data set and methods. The station network shown in Fig. 1 has remained unchanged from that presented in Alexandersson et al. (1998). For each station 3 observations per day have been digitised or extracted from existing computer files. Most of the series started within the period 1860 to 1900 , but for quality reasons we did not extend our analyses back before 1881 . Geostrophic winds were calculated using triangles of stations. For each year 95 and 99 percentiles were derived. These percentiles give a measure of the synoptic-scale storminess of each year. Then area averages were calculated, not using the percentiles per triangle as such but standardised values, i.e. percentile values minus averages divided by standard deviations. Two areas were defined: one more maritime, westerly

*E-mail: hans.alexandersson@smhi.se area called 'British Isles, North Sea, Norwegian Sea', one more continental, easterly area called 'Scandinavia, Finland, Baltic Sea'. The triangles within each area are given in Table 1.

Results. Figs. $2 \& 3$ show the updated versions of the 2 area-averaged time series and low-pass filtered curves. Only 3 years have been added to the corresponding plots in Alexandersson et al. (1998), but it is interesting to update these curves as they ended at

Table 1. Triangles used to construct mean values within the 2 areas. The time period that was used is given for each triangle

\begin{tabular}{|ll|}
\hline Triangle & Time period \\
\hline 'British Isles, North Sea, N orwegian Sea' & \\
Torshavn-Stykkisholmur-Bodø & $1900-1998$ \\
Bergen-Torshavn-Aberdeen & $1881-1998$ \\
Torshavn-Bodø-Bergen & $1900-1998$ \\
Aberdeen-Valentia-Torshavn & $1892-1998$ \\
Bergen-Vestervig-Aberdeen & $1881-1998$ \\
Aberdeen-Valentia-de Bilt & $1902-1998$ \\
Aberdeen-Vestervig-de Bilt & $1902-1998$ \\
Valentia-Stykkisholmur-Torshavn & $1892-1998$ \\
Jan Mayen-Stykkisholmur- Bodø & $1922-1998$ \\
Torshavn-Nordby-Bergen & $1881-1998$ \\
'Scandinavia, Finland, Baltic Sea' & \\
Härnösand- Bodø-Haparanda & $1900-1998$ \\
Helsinki-Härnösand-Kajaani & $1887-1998$ \\
Stockholm-Härnösand-Bergen & $1881-1998$ \\
Stockholm-Helsinki-Härnösand & $1881-1998$ \\
Vestervig-Nordby-Lund & $1881-1998$ \\
Stockholm-Visby-Helsinki & $1881-1998$ \\
Visby-Göteborg-Lund & $1881-1998$ \\
Bergen-Stockholm-Nordby & $1881-1998$ \\
Oksøy-Göteborg-Nordby & $1881-1998$ \\
Bergen- Bodø-Härnösand & $1900-1998$ \\
\hline
\end{tabular}




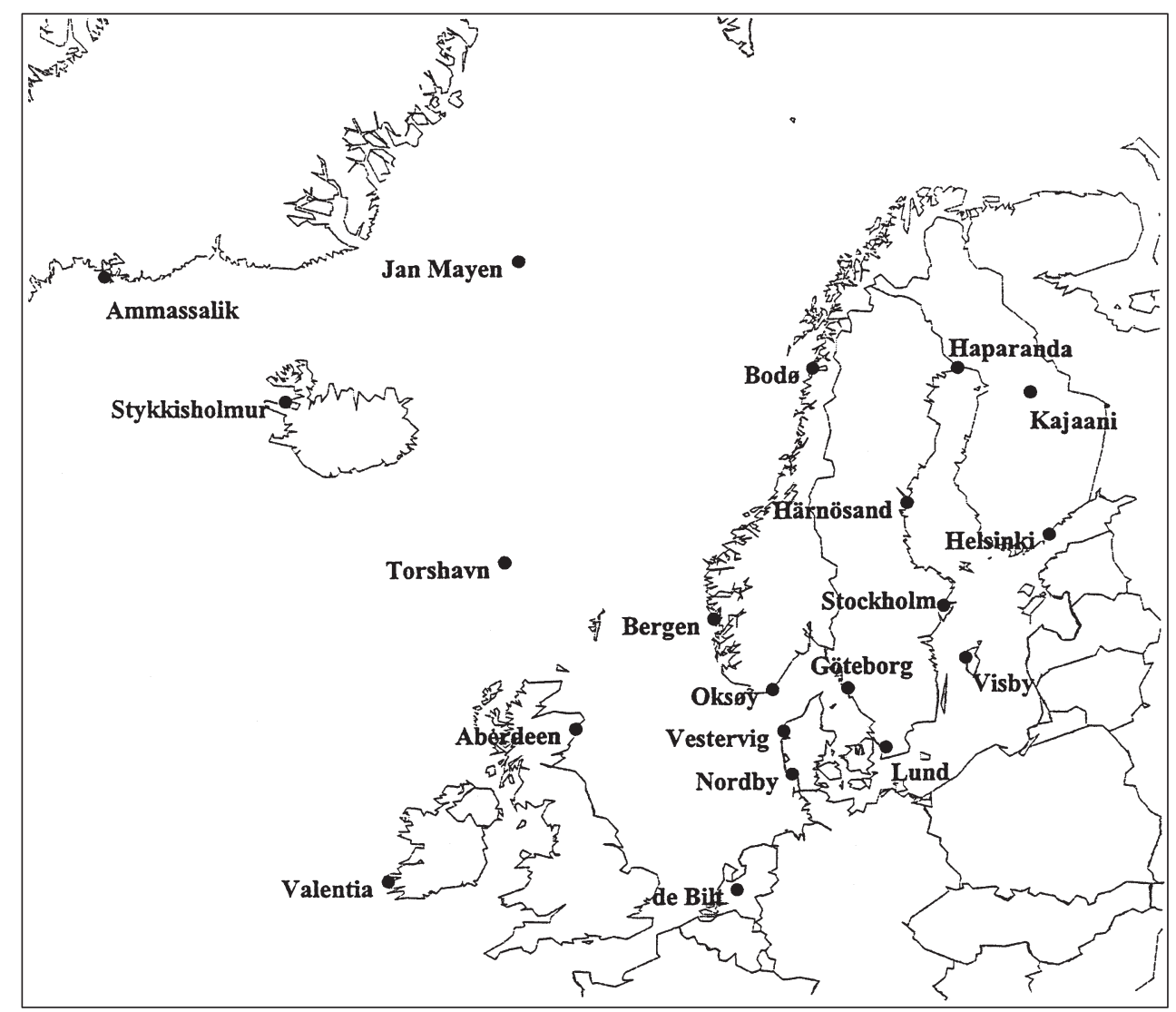

Fig. 1. Stations with long time series of 3 pressure observations per day

British Isles, North Sea, Norwegian Sea, 1881-1998

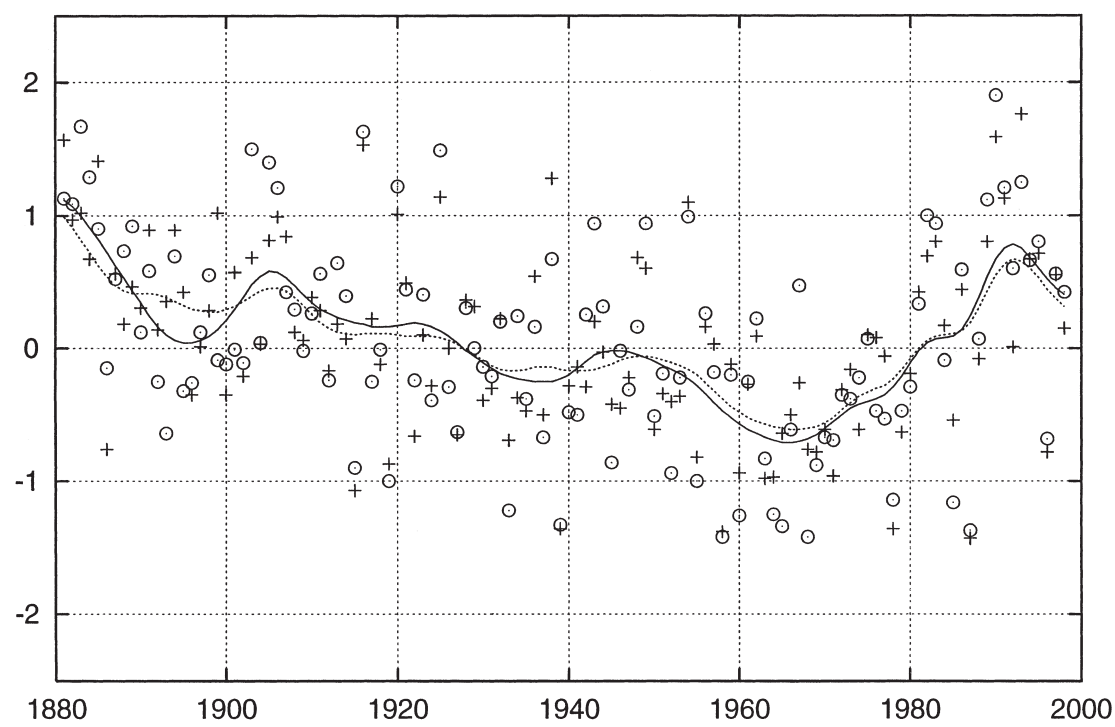

Fig. 2. Average of standardised $95(+)$ and $99(\odot)$ percentiles and corresponding smoothed curves (solid and dotted lines respectively), 1881 to 1998, westerly area 
Scandinavia, Finland, Baltic Sea, 1881-1998

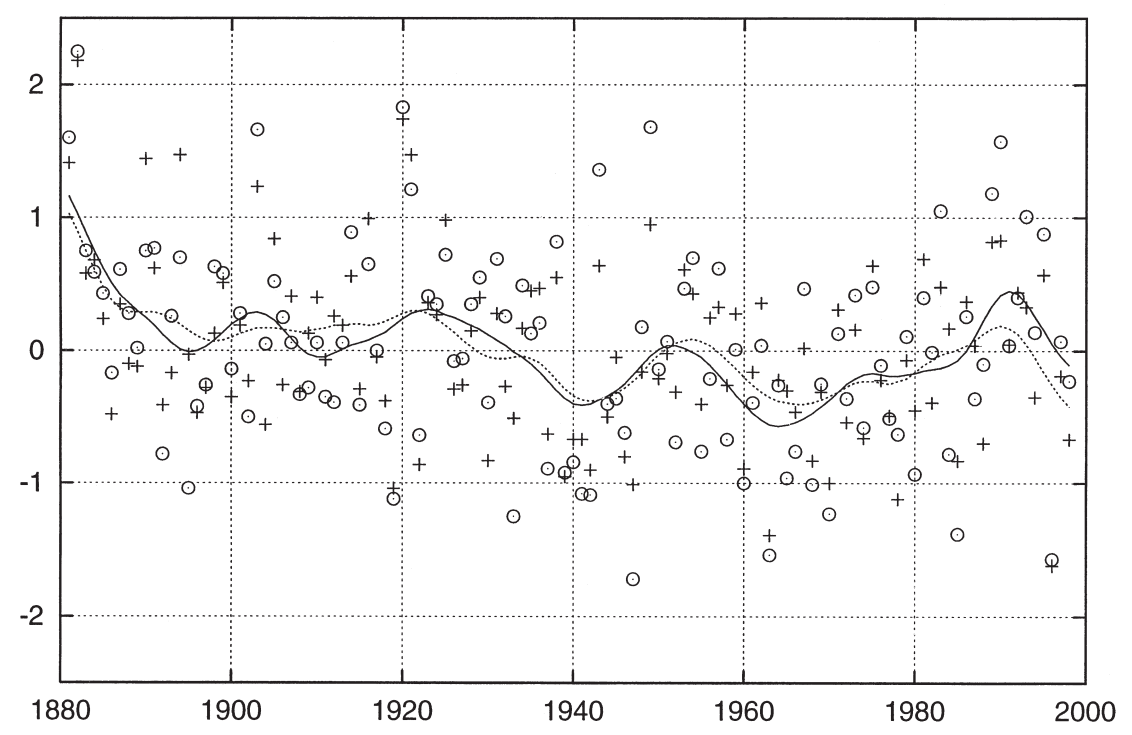

Fig. 3. Average of standardised 95 (+) and $99(\odot)$ percentiles and corresponding smoothed curves (solid and dotted lines respectively), 1881 to 1998 , easterly area

such high levels. Have the storms reached their maximum now?

In the easterly area, 1996 was a very weak storm year with mostly anticyclonic, cold and calm conditions in J anuary, February, November and December, normally the stormiest months of the year. 1997 and 1998 were close to or slightly below the long-term average, so that the smoothed curves (low-pass-filter curves using Gaussian weights), corresponding to $10 \mathrm{yr}$ moving averages, now clearly have gone down from the maximum around 1990. It is, however, dangerous to trust too much in the tails of these smoothed curves, as they will change when new data points are added.

In the westerly area, 1996 was also a weak year for storms, but 1997 and 1998 turned out to be slightly above the long-term average, so that the smoothed

Editorial responsibility: Hans von Storch, Geesthacht, Germany curves still are above the zero line. But also here there is a clear tendency of a reduction in storminess after the maximum around 1990. As this recent, stormier period seems to be broken in northwestern Europe, the 1880s still appear as the most prominent storm decade during the $120 \mathrm{yr}$ of high-quality observations of air pressure.

\section{LITERATURE CITED}

Alexandersson H, Schmith T, Iden K, Tuomenvirta H (1998) Long-term variations of the storm climate over NW Europe. Global Atmos Ocean Syst 6:97-120

von Storch $\mathrm{H}$ and 30 co-authors (1998) Changing waves and storms in the northeast Atlantic? Bull Am Meteorol Soc 79(5):741-760

Submitted: September 10, 1999; Accepted: September 11, 1999 Proofs received from author(s): December 13, 1999 